\title{
Alteration zonation in the Loma Blanca kaolin deposit, Los Menucos, Province of Rio Negro, Argentina
}

\author{
Presented at the XIV International Clay Conference, Castellaneta Marina, Italy, June 2009 \\ S. A. MARFIL ${ }^{1,2, *}$, P. J MAIZA ${ }^{1,3}$ AND N. MONTECCHIARI ${ }^{1}$ \\ ${ }^{1}$ Department of Geology - INGEOSUR, Universidad Nacional del Sur, San Juan 670, 8000 Bahía Blanca, Argentina, \\ ${ }^{2}$ Independent Researcher at CIC de la Provincia de Buenos Aires, Argentina, and ${ }^{3}$ Principal Researcher at CONICET. \\ Argentina
}

(Received 19 August 2009; revised 29 October 2009; Editor: John Adams)

\begin{abstract}
The Loma Blanca mine is in one of the northwest kaolinized zones of the Los Menucos area (Patagonia, Argentina). The parent rocks are andesites and andesitic tuffs from the Vera Formation, Los Menucos Group (Lower Triassic). Hayase \& Maiza (1974) proposed a concentric zonation model. From the parent rock outward, four different alteration patterns were recognized: Zone 1, with sericite, chlorite and montmorillonite; Zone 2, with kaolinite and dickite; Zone 3, with dickite, pyrophyllite and alunite; and Zone 4, with quartz, disseminated sulphides and diaspore.

The relationship between the chemical composition of major, minor and trace elements and the mineralogical alteration zonation was evaluated to confirm the genesis of the deposit. $\mathrm{Fe}_{2} \mathrm{O}_{3}, \mathrm{CaO}$, $\mathrm{Na}_{2} \mathrm{O}$ and $\mathrm{K}_{2} \mathrm{O}$ contents decrease from Zone 1 to Zone 3, whereas $\mathrm{Al}_{2} \mathrm{O}_{3}$ and LOI increase in the kaolinite-alunite zone. In the chemical composition of alunite, $\mathrm{Na}>\mathrm{K}$. Large $\mathrm{Ba}, \mathrm{Sr}, \mathrm{V}$ and $\mathrm{Zr}$ contents were observed mainly in Zones 2 and 3. $\mathrm{Co}, \mathrm{Ni}, \mathrm{Cu}, \mathrm{Zn}$ and $\mathrm{Rb}$ are more common in Zone 1. LREE are more abundant than HREE in Zones 2 and 3. In kaolinites $\delta^{18} \mathrm{O}$ values range from $10.8 \%$ to $13.2 \%$, and $\delta \mathrm{D}$ from $-83 \%$ to $-85 \%$.

The mineral assemblage (dickite-alunite-pyrophyllite-diaspore), the alteration zonation pattern (laterally concentric), the geochemistry of trace elements, the relation between LREE and HREE and the small $\delta^{18} \mathrm{O}$ values suggest that the Loma Blanca deposit was formed by hydrothermal processes.
\end{abstract}

KEYWORDS: geochemistry, kaolin, chlorite, kaolinite, dickite, pyrophyllite, Loma Blanca deposit, Argentina.

In the province of Río Negro (Patagonia, Argentina) there are a large number of kaolin deposits hosted by volcanic rocks of the Los Menucos Group. The sequence starts with andesitic volcanism and ends with rhyolitic pyroclastic facies. Most of the kaolin deposits are hosted by rhyolitic tuffs (Sierra Colorada Formation) of Upper Triassic to Middle

* E-mail: smarfil@uns.edu.ar

DOI: $10.1180 /$ claymin.2010.045.2.145
Jurassic age. These mines have been extensively studied (Maiza, 1972; Maiza \& Mas, 1981; Marfil et al., 2000; and Maiza et al., 2003). Loma Blanca is one of the northernmost kaolinized zones in the area and is the only deposit hosted by andesitic rocks.

Terakado \& Fujitani (1998) studied the rare earth elements and other trace elements in silicastones, alunites and related rocks in order to examine the behaviour of trace elements in the acidic hydrothermal alteration of silicic volcanic rocks. They found that most of the elements such as $\mathrm{Na}, \mathrm{Fe}, \mathrm{Ba}$ 
and $L R E E$ were leached from the silicastones, while HREE, Th, Hf and $\mathrm{Zr}$ were retained in the rocks, even under strongly acidic hydrothermal processes. Alunite samples have LREE-enriched and HREEdepleted features.

According to Dill et al. (1997), the ratios $\mathrm{TiO}_{2}+$ $\mathrm{Fe}_{2} \mathrm{O}_{3}$ vs. $\mathrm{Cr}+\mathrm{Nb}, \mathrm{Zr}$ vs. $\mathrm{TiO}_{2}$ and $\mathrm{Ba}+\mathrm{Sr} v s . \mathrm{Ce}$ $+\mathrm{Y}+\mathrm{La}$ in kaolinites allow discrimination between hypogene and supergene kaolinization processes. The APS-bearing argillaceous zones that formed during supergene processes are significantly enriched in REE relative to hypogene equivalents (Dill, 2001).

Pandarinath et al. (2008) studied the effects of hydrothermal alteration on major, rare-earth, and other trace-element concentrations in rhyolitic rocks of the Los Azufres geothermal field, Mexico. They concluded that the hydrothermal alteration resulted in a decrease in $\mathrm{MnO}, \mathrm{P}_{2} \mathrm{O}_{5}, \mathrm{Ta}, \mathrm{Rb} / \mathrm{Zr}$ and $\mathrm{Rb} / \mathrm{Nb}$, and an increase in $\mathrm{Zr}, \mathrm{Nb}$ and $\mathrm{Nb} / \mathrm{Y}$. The greater variances of several chemical variables in altered rocks $(\mathrm{Y}, \mathrm{Ce}, \mathrm{Pr}, \mathrm{Nd}, \mathrm{Sm}, \mathrm{Lu}$ and $\mathrm{Pb}$ ) are probably due to hydrothermal processes, whereas smaller variances of other altered rock variables $(\mathrm{CaO}, \mathrm{Sr}$, $\mathrm{Rb} / \mathrm{Sr}$ and $\mathrm{Rb} / \mathrm{Ba}$ ) suggest that these processes led to more uniform chemical rock compositions. The concentrations of REE were not significantly different between fresh and altered rhyolitic rocks, which implies that either these elements remained immobile or were reincorporated into secondary minerals during the hydrothermal alteration of the rhyolitic rocks.

Papoulis \& Tsolis-Katagas (2008) studied kaolin deposits in the western and southern parts of Limnos Island, northeast Aegean Sea, Greece, and they found four types of hydrothermal alteration zones: smectite-illite-halloysite and kaolinitedickite-rich zones. Mineral assemblages reveal that temperatures ranged from $<100^{\circ} \mathrm{C}$ (smectite-rich and halloysite-rich zones) to $\sim 270^{\circ} \mathrm{C}$ (kaolinitedickite-rich zones). Limited supergene alteration was observed in the less hydrothermally altered rocks of the illite-rich zones as suggested by the presence of jarosite and pyrite. The development of the various assemblages depends not only on the temperature and composition of the hydrothermal fluids but also on the distance of the rock from the fault or the channel of the ascending hydrothermal fluids.

Papoulis et al. (2004) used the $\mathrm{K}$ and $\mathrm{Na}$ content in a kaolin deposit from Greece to measure the degree of alteration of primary rocks. The positive correlation between $\mathrm{Al}_{2} \mathrm{O}_{3}$ and LOI and the large negative loadings between $\mathrm{SiO}_{2}-\mathrm{Al}_{2} \mathrm{O}_{3}$ and $\mathrm{SiO}_{2}$-LOI indicate that LOI and $\mathrm{Al}_{2} \mathrm{O}_{3}$ contents increase in the more altered samples.

Ece et al. (2008) studied acid-sulphate hydrothermal alteration in andesitic tuffs in the Biga Peninsula (Turkey) and concluded that the changes in the chemical composition of geothermal waters through time and the chemistry of the intermediate products in clay deposits also control the formation of alunite. The main geothermal activity and acidsulphate alterations for the mineralizations of alunite and halloysite occurred after the onset of NAF-related faulting in the Biga Peninsula. The $\mathrm{P}_{2} \mathrm{O}_{5}$ enrichment in alunite nodules suggests a deep magmatic source for the geothermal waters that passed through the shallow-level granodiorite intrusions.

The aim of the work described in this paper was to evaluate the relation between the chemical composition of major, minor and trace elements, the stable isotopes in kaolin (O and D) and the mineralogical alteration zonation to confirm the genesis of the deposit.

\section{GEOLOGICAL SETTING AND MINERALOGY}

Loma Blanca is situated $70 \mathrm{~km} \mathrm{NW}$ of Los Menucos (Río Negro Province, Argentina) (Fig. 1). The parent rocks are andesites and their tuffs from the Vera Formation (Lower Triassic) (Los Menucos Group), which lie unconformably on the La Esperanza granite and Colo Niyeu methamorphites. $150 \mathrm{~m}$ to the northeast of the deposit there is an outcrop of granite intruded by aplitic dykes. Its geological importance arises from the mineralogy, structure and setting of the strongly mineralized area and its relationship with the different lithologic units.

Hayase \& Maiza (1974) studied the mineralogy of the Loma Blanca deposit using XRD, TG, DTA and microscopy. They concluded that the deposit was formed by the activity of an acid hydrothermal solution or superheated solfatara. They proposed a concentric zonation model. From the parent rock outward, different alteration patterns were recognized: a zone with sericite, chlorite and montmorillonite; a zone with kaolinite and dickite; a zone with dickite, pyrophyllite and alunite-natroalunite; and a zone with quartz, disseminated sulphides and diaspore (Fig. 2). 


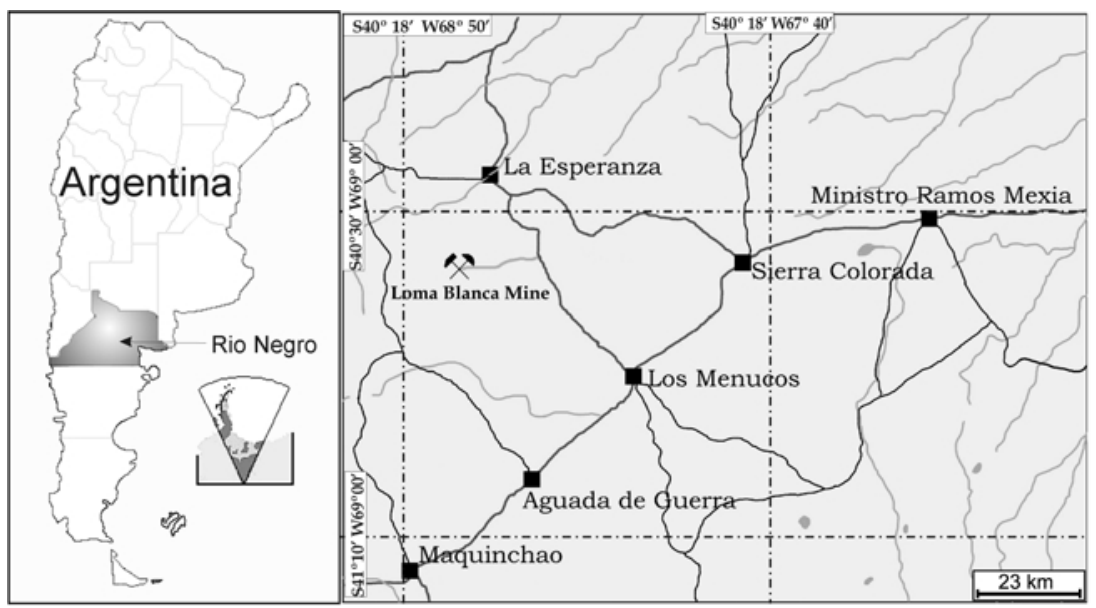

FIG. 1. Location of the Loma Blanca mine.

The structure is not clearly exposed due to the scarce outcrops and smooth geomorphical topography covered by recent sediments. Geological evidence from the area indicates the development of tectonic fracturing and differential block movements affecting the heterogeneous volcanosedimentary pile that channelled the hydrothermal solutions responsible for the mineralization. The mineral assemblage, with high-temperature minerals (diaspore, pyrophyllite and dickite), the abovementioned sulphides, the areal structure and favourable lithology related to mineralization processes identify this zone as suitable for metallic mineral prospecting.

The floor of the Loma Blanca mine consists of andesite that shows progressive alteration and development of a propylitic zone. Tuffaceous levels are transitionally interlayered; they are affected by tectonics and have developed breccia zones that, owing to their greater permeability, provide pathways for mineralizing solutions. Towards the top of the mineralized zone, the texture is obliterated due to the intense silicification that has erased the lithological characteristics of the affected rocks (Maiza et al., 2009).

The oldest formation in the area is Colo Niyeu, which is a low-grade metasedimentary basement. According to Labudia \& Bjerg (1994), it could only be assigned a pre-Permian age. This unit was intruded by different plutonites of the so-called Complejo Plutónico La Esperanza. Close to the deposit, outcrops attributed to the Donosa granite, due to their mineralogical and textural characteristics, were recognized; the age of the intrusion,according to Pankurst et al. (1992), will be Late Permian. Over these formations lie the lithologic

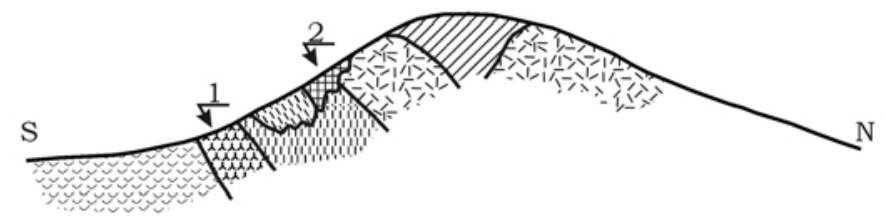

\begin{tabular}{|c|c|c|}
\hline QIIA Silicification & 巴曲曲 Dickite, pyrophyllite, sericite & ECY Pyrophyllite \\
\hline 原资 Kaolinite & Gin Sericite, Kaolinite, secondary Quartz & Quarry $N^{\circ} 1$ \\
\hline Caolinite & hlorite, Sericite, Montmorillo & 2 \\
\hline
\end{tabular}

FIG. 2. Scheme of the Loma Blanca mine (after Hayase \& Maiza, 1974). 
components of the Los Menucos Group, of Triassic age; they are intruded by andesitic dykes of the Taquetren Formation. The field relations of these units have been obscured by tectonism, covered by recent sediments and masked by the mineralizing process.

\section{SAMPLING}

Twenty samples were collected from the propylitic zone (Fig. 3a) to the advanced argillic zone (Fig. 3b); two profiles were in the intermediate argillic alteration zone (samples 08 to 10 from bottom to top) and in the advanced argillic alteration zone (samples 16 to 20 from top to bottom).

\section{ANALYTICAL METHODS}

A petrographic and mineralogical study of representative samples from the different alteration zones was carried out. Texture, morphology and space relations between the different alteration minerals were studied. An Olympus B2-UMA trinocular petrographic microscope with a built-in Sony 151A video camera, a high-resolution monitor and Image-Pro Plus image processing software were used. The mineralogical composition of bulk samples was determined by an X-ray diffractometer, using Rigaku D-Max III, with $\mathrm{Cu}-\mathrm{K} \alpha$ radiation of wavelength $\lambda=1.54178 \AA$ and a graphite monochromator operated at $35 \mathrm{kV}$ and $15 \mathrm{~mA}$. Diffractograms were recorded from $2^{\circ}$ to $60^{\circ} 2 \theta$. Chemical analyses of bulk samples for

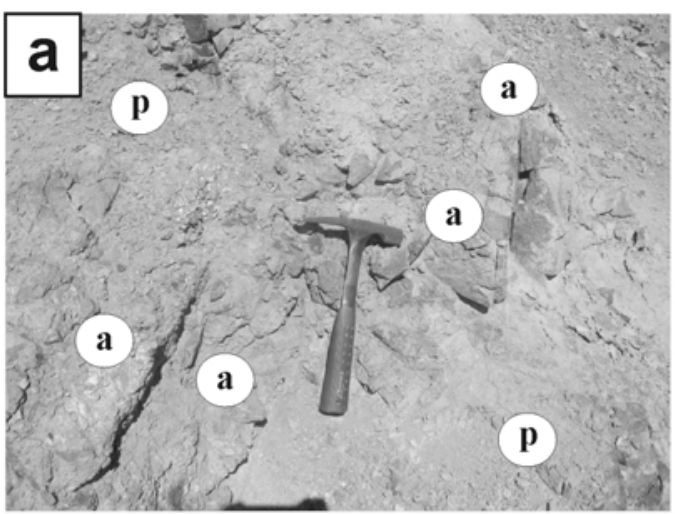

major, minor and trace elements were carried out by ICP at Activation Laboratories Ltd. (ACTLABS, Canada).

Kaolinite samples were selected for $\mathrm{H}$ and $\mathrm{O}$ isotope analyses. Stable isotope analyses were carried out at ACTLABS. Results are presented as $\%$ deviation with respect to SMOW. The reproducibility of results is better than $\pm 0.5 \%$ for $\mathrm{O}$ and $\pm 10 \%$ for $\mathrm{H}$.

\section{RESULTS}

\section{$X$-ray diffraction}

The minerals identified by X-ray diffraction (XRD) are listed in Table 1. When kaolinite and dickite are associated, it is very difficult to differentiate them by this method. The two triplets located between $34^{\circ}$ and $40^{\circ} 2 \theta$ were studied in detail. Dickite appears in very small proportions compared with kaolinite in the samples of the advanced argillic alteration zone (Fig. 4). In this zone, besides alunite, diaspore at the top and pyrophyllite in the highest area of the profile (samples 16 and 17) were identified. These minerals are found in isolated masses within the area of greatest hydrothermal activity as relicts of a first stage of higher pressure and temperature.

The characteristic diffraction patterns for each alteration zone are shown in Fig. 5. Figure 5a shows the propylitic alteration zone, where chlorite and scarce illite can be identified. Feldspar from the andesitic rock is still present. Figure $5 \mathrm{~b}$ depicts the quartz-sericitic zone. The predominant alteration



FIG. 3. (a) Propylitic alteration zone: $a=$ andesite; $p=$ propylitic area. (b) Advanced argillic alteration zone: $d i=$ dickite; py $=$ pyrophyllite; $\mathrm{ds}=$ diaspore. 
TABLE 1. Main minerals identified by XRD.

\begin{tabular}{llll}
\hline Sample & \multicolumn{1}{c}{ Clay minerals } & \multicolumn{1}{c}{ Other minerals present } & \multicolumn{1}{c}{ Alteration } \\
\hline 01 & Chlorite & Feldspar-quartz & Propylitic \\
02 & Chlorite $>$ illite & Feldspar-quartz & \\
03 & Chlorite $>$ illite & Feldspar-quartz & \\
04 & Illite $>$ chlorite & Feldspar - quartz & Sericitic \\
05 & Illite & Quartz & \\
06 & Kaolinite & Quartz & Intermediate \\
07 & Kaolinite & - & argillic \\
08 & Kaolinite & Quartz & \\
09 & Kaolinite & Quartz & \\
10 & Kaolinite & Quartz & Silicified zone \\
11 & Kaolinite & Quartz & \\
12 & Kaolinite & Quartz & Advanced argillic \\
13 & Kaolinite & Natroalunite-quartz & \\
14 & Kaolinite $>$ dickite & Natroalunite- diaspore-quartz & \\
15 & Kaolinite $>$ dickite & Natroalunite-quartz & \\
16 & Kaolinite $>$ dickite-pyrophyllite & Natroalunite-quartz & \\
17 & Kaolinite $>$ dickite-pyrophyllite & Natroalunite-quartz & \\
18 & Kaolinite $>$ dickite & Natroalunite-quartz & \\
19 & Kaolinite $>$ dickite & Natroalunite- quartz & \\
20 & Kaolinite $>$ dickite & & \\
& & & \\
\hline
\end{tabular}

mineral is illite together with abundant quartz. Figure $5 \mathrm{c}$ shows the intermediate argillic alteration zone. Kaolinite and quartz reflections can be identified. The diffraction pattern of the silicified zone (Fig. 5d) is similar to that of Fig. 5 c, but in the latter quartz predominates over kaolin. Figure $5 \mathrm{e}$ shows the characteristic minerals of the advanced argillic zone. Kaolinite, dickite, natroalunite, diaspore and quartz can be identified.

\section{PETROGRAPHY}

Propylitic alteration zone (samples 01 to 03)

The original texture is preserved. Plagioclase (andesine) crystals are altered, mainly to illite and calcite. Chlorites are found due to Fe availability. Plagioclase crystals of the groundmass are slightly more sodic, although they are still andesinic. Chlorite pseudomorphically replaces the mafic

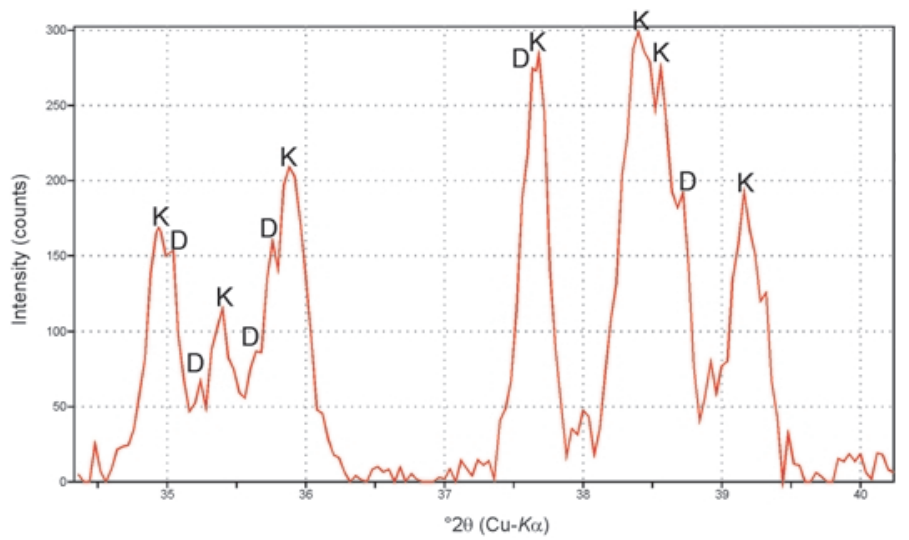

FIG. 4. Detail of the triplets located between 34 and $40^{\circ} 2_{y}$ where kaolinite and dickite can be seen. 


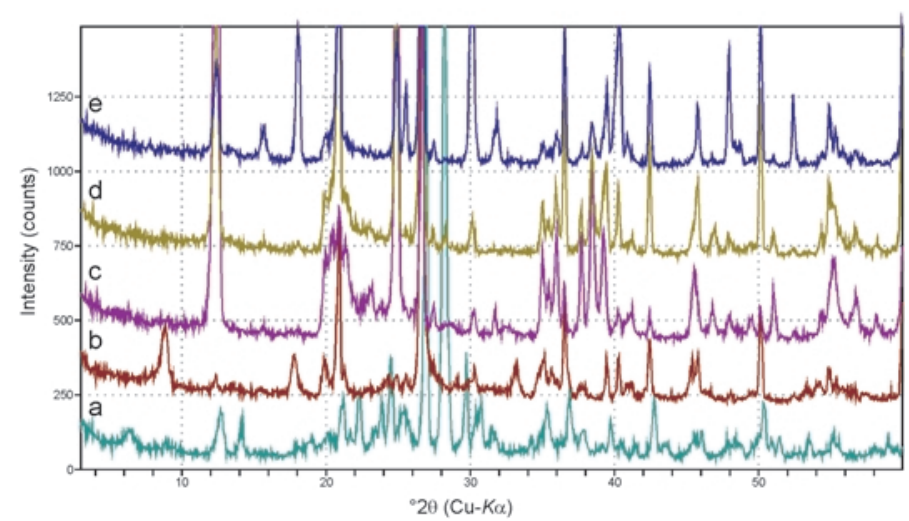

FIG. 5. Minerals of the different alteration zones identified by XRD. (a) Propylitic zone; (b) sericitic zone; (c) intermediate argillic zone; (d) silicified zone; (e) advanced argillic zone.

minerals, and goethite is formed from the remaining $\mathrm{Fe}$ (Fig. 6A). Saccharoidal quartz is found as patches in the groundmass.

Two types of chlorites are recognized: a bluish low-pleochroic form (interpreted as rich-Mg, lowAl-type sheridinite) and the other, brownish grey, highly pleochroic, low interference colour, closely related to $\mathrm{Fe}$ oxides, thuringite (ripidolite).

\section{Sericitic alteration zone (samples 04 and 05)}

The andesitic tuff is highly altered. The groundmass is completely argilized with secondary quartz. Iron oxides stain the whole rock (Fig. 6B). Sericite is the main alteration product. Quartz forms saccharoidal textures where three or more anhedral crystals are grouped. No original minerals are preserved.

\section{Intermediate argillic alteration zone (samples 06 to 10 )}

The andesitic tuff is completely kaolinized. There is a stockwork of pure dickite veins, where the area between the veins is composed of a quartz-dickite association with variable amounts of illite-3T, and scarce Al hydroxides (diaspore). There are veins of dickite associated with boehmite crystals. A relic of highly altered, mainly silicified, host rock is found between the veins (Fig. 6C).

\section{Silicified zone (samples 11 to 13)}

Diaspore was positively identified in this zone and is closely related to dickite (Fig. 6D).
Advanced argillic alteration zone (samples 14 to 20)

This zone develops at the top of the hill coinciding with the greatest mineralization. The texture resembles that of tuff with lithic clasts replaced by natroalunite. There is no relict quartz. The groundmass is an association of quartz-kaolin and metallic minerals. Hydroxides of Al can be recognized in certain areas. Natroalunite is abundant in this area and is associated with dickite and pyrophyllite (Fig. 6E). Figure $6 \mathrm{~F}$ shows diaspore twinned crystals, where kaolin has pseudomorphically replaced the core.

\section{CHEMICAL COMPOSITION}

Major elements analyses are shown in Table 2, and trace element contents are included in Table 3. $\mathrm{Fe}_{2} \mathrm{O}_{3}, \mathrm{CaO}, \mathrm{Na}_{2} \mathrm{O}$ and $\mathrm{K}_{2} \mathrm{O}$ contents decrease from propylitic to advanced argillic alteration zones, whereas $\mathrm{Al}_{2} \mathrm{O}_{3}$ and LOI increase in the kaolinitenatroalunite zone.

Natroalunite was identified by XRD and with a petrographic microscope in samples 14 to 20 . Natroalunite composition was determined by XRD using basal reflections (003, 006 and 009). Maiza \& Mas, 1980, synthesized the minerals of the series from sericite alteration in a $\mathrm{H}_{2} \mathrm{SO}_{4}$ solution with varying amounts of $\mathrm{KCl}$ and $\mathrm{NaCl}$. They determined the $c_{\mathrm{o}}$ values in each of the products obtained and checked them by chemical analysis. With these values they fitted a straight line by the least-squares method. The calculated value for natroalunite from 

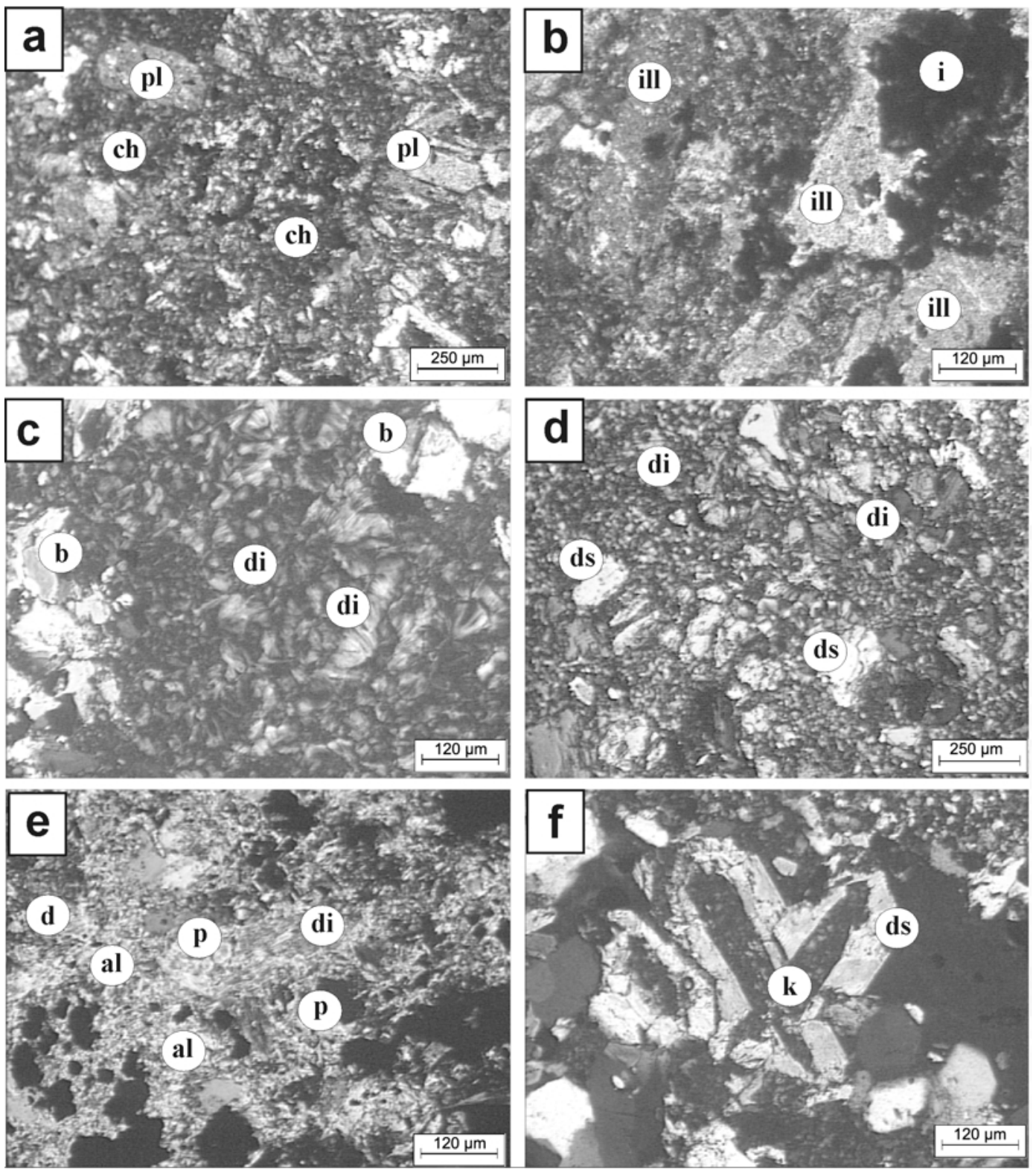

Fig. 6. (A) Propylitic zone: andesite texture is preserved. Plagioclase (pl) is altered to illite. Chlorites (ch) are abundant. (B) Sericitic zone: andesitic tuff is altered mainly to illite (ill). Fe oxides stain the whole rock (i). (Cc) Intermediate argillic alteration zone. Veins of dickite (di) are associated with boehmite crystals (b). (D) Silicified zone. Diaspore (d) is closely related to dickite (di). (E) Advanced argillic alteration zone: alunite (al) is associated with dickite (di) and pyrophyllite (p). (F) Diaspore twinned crystals (ds) have pseudomorphically replaced kaolin (k).

Loma Blanca is $16.83 \AA$, which corresponds to $87 \%$ $\mathrm{Na}$. The formula calculated on this basis is $\left(\mathrm{Na}_{0.13} \mathrm{~K}_{0.87}\right) \mathrm{Al}_{3}\left(\mathrm{SO}_{4}\right)_{2}(\mathrm{OH})_{6}$. The percentage of this mineral, calculated from the $\mathrm{S}$ content, ranges between $2 \%$ and $25 \%$. The sulphur content in samples 01 to 13 is attributed to the sulphides 
TABLE 2. Chemical analyses of major elements in whole-rock samples from the Loma Blanca mine (wt.\%).

\begin{tabular}{llllllllllllllr}
\hline Sample & $\mathrm{SiO}_{2}$ & $\mathrm{Al}_{2} \mathrm{O}_{3}$ & $\mathrm{Fe}_{2} \mathrm{O}_{3}$ & $\mathrm{MnO}$ & $\mathrm{MgO}$ & $\mathrm{CaO}$ & $\mathrm{Na}_{2} \mathrm{O}$ & $\mathrm{K}_{2} \mathrm{O}$ & $\mathrm{TiO}_{2}$ & $\mathrm{P}_{2} \mathrm{O}_{5}$ & $\mathrm{~S}$ & LOI & Total \\
\hline 01 & 60.22 & 17.35 & 6.55 & 0.075 & 1.43 & 1.20 & 5.42 & 0.96 & 0.790 & 0.29 & 0.04 & 5.16 & 99.45 \\
02 & 58.82 & 17.08 & 5.10 & 0.083 & 2.11 & 2.86 & 5.26 & 1.00 & 0.744 & 0.25 & 0.05 & 5.47 & 98.78 \\
03 & 57.74 & 17.84 & 5.43 & 0.060 & 1.89 & 2.11 & 5.74 & 0.91 & 0.803 & 0.27 & 0.04 & 5.58 & 98.38 \\
04 & 62.3 & 17.28 & 7.05 & 0.497 & 0.78 & 0.44 & 0.26 & 2.28 & 0.718 & 0.24 & 0.04 & 6.91 & 98.77 \\
05 & 63.14 & 16.08 & 9.45 & 0.027 & 0.39 & 0.24 & 0.52 & 3.01 & 0.933 & 0.35 & 0.21 & 6.17 & 100.30 \\
06 & 51.08 & 32.52 & 0.35 & 0.002 & 0.03 & 0.13 & 0.07 & 0.15 & 0.554 & 0.19 & 0.23 & 12.85 & 97.93 \\
07 & 59.01 & 28.39 & 0.11 & $<0.001$ & 0.02 & 0.09 & 0.05 & $<0.01$ & 0.737 & 0.17 & 0.16 & 10.89 & 99.46 \\
08 & 44.88 & 38.68 & 0.12 & $<0.001$ & 0.02 & 0.05 & 0.07 & 0.06 & 0.101 & 0.13 & 0.13 & 14.43 & 98.52 \\
09 & 49.99 & 33.33 & 0.04 & $<0.001$ & 0.14 & 0.08 & 0.37 & 0.13 & 0.913 & 0.21 & 0.26 & 13.23 & 98.42 \\
10 & 60.9 & 27.05 & 0.11 & 0.005 & 0.03 & 0.06 & 0.12 & 0.33 & 0.954 & 0.20 & 0.43 & 10.64 & 100.40 \\
11 & 65.93 & 18.85 & 4.73 & 0.001 & 0.07 & 0.22 & 0.25 & 0.79 & 0.910 & 0.30 & 0.24 & 8.79 & 100.80 \\
12 & 67.08 & 21.43 & 0.13 & $<0.001$ & 0.02 & 0.05 & 0.09 & 0.13 & 0.787 & 0.18 & 0.36 & 9.03 & 98.92 \\
13 & 67.43 & 21.05 & 0.06 & $<0.001$ & 0.01 & 0.97 & 0.09 & 0.14 & 0.755 & 0.16 & 0.33 & 9.12 & 99.78 \\
14 & 56.87 & 17.35 & 3.96 & 0.001 & 0.09 & 0.57 & 1.09 & 0.59 & 0.854 & 0.25 & 3.68 & 16.38 & 98.00 \\
15 & 64.18 & 16.28 & 5.04 & $<0.001$ & 0.06 & 0.41 & 0.34 & 0.18 & 0.775 & 0.80 & 1.41 & 10.12 & 98.19 \\
16 & 65.82 & 18.41 & 1.02 & $<0.001$ & 0.02 & 0.11 & 0.63 & 0.41 & 0.931 & 0.22 & 1.94 & 11.80 & 99.38 \\
17 & 54.68 & 20.34 & 0.96 & $<0.001$ & 0.01 & 0.13 & 1.44 & 1.01 & 0.860 & 0.28 & 4.78 & 18.81 & 98.53 \\
18 & 69.18 & 16.25 & 0.09 & $<0.001$ & $<0.01$ & 0.13 & 0.67 & 0.42 & 0.872 & 0.31 & 2.08 & 11.35 & 99.28 \\
19 & 65.52 & 16.95 & 0.23 & $<0.001$ & 0.03 & 0.11 & 0.69 & 0.45 & 0.871 & 0.21 & 2.70 & 15.91 & 101.00 \\
20 & 34.02 & 37.82 & 0.22 & $<0.001$ & 0.05 & 0.15 & 1.21 & 0.93 & 1.123 & 0.52 & 3.68 & 23.03 & 99.07 \\
& & & & & & & & & & & & & \\
\hline
\end{tabular}

present (covellite, sphalerite and pyrite). Sulphides were identified with a petrographic microscope on polished sections in almost all the samples, so the total percentage of natroalunite is considered to be slightly smaller than the calculated value.

Large $\mathrm{Ba}, \mathrm{Sr}, \mathrm{V}$ and $\mathrm{Zr}$ contents were observed, mainly in intermediate argillic and advanced argillic zones. $\mathrm{Co}, \mathrm{Ni}, \mathrm{Cu}, \mathrm{Zn}$ and $\mathrm{Rb}$ are more common in the propylitic zone. $\mathrm{Be}, \mathrm{Ge}, \mathrm{In}, \mathrm{Sn}, \mathrm{Mo}, \mathrm{Nb}$ and $\mathrm{Ag}$ are insignificant in all the samples.

$\mathrm{Ba}+\mathrm{Sr}$ vs. $\mathrm{Ce}+\mathrm{Y}+\mathrm{La}, \mathrm{Fe}_{2} \mathrm{O}_{3}+\mathrm{TiO}_{2}$ vs. $\mathrm{Cr}+$ $\mathrm{Nb}$ and $\mathrm{Zr} v s$. $\mathrm{TiO}_{2}$ plots are shown in Fig. 7.

The chondrite-normalized REE diagram according to Boynton, 1984 (Rollinson, 1992), for the samples of the propylitic and sericitic alteration zones are shown in Fig. 8a and b for the samples of intermediate and advanced argillic alteration zones. In the latter, especially in pure kaolin samples such as 08 , there is marked LREE impoverishment with respect to HREE, especially when compared with the less altered samples (Fig. 8a). There is no evidence of a positive Ce anomaly, which is typical of the deposits of residual and/or meteoric origin (Cravero et al., 2001).

LREE are more abundant than HREE in the intermediate argillic alteration and advanced argillic alteration zones.

\section{$O$ and $H$ isotopes}

$\delta^{18} \mathrm{O}$ and $\delta \mathrm{D} \%$ values of kaolin samples from the Loma Blanca mine are shown in Table 4. $\delta^{18} \mathrm{O}$ values in kaolinites range from $10.8 \%$ to $13.2 \%$, and $\delta \mathrm{D}$ from $-83 \%$ to $-85 \%$. Although these values are within the range of variation for hydrothermal kaolins (Murray \& Janssen, 1984), they are larger than those determined for other deposits in the area (Blanquita and Equivocada mines, Marfil et al., 2005), where $\mathrm{O}$ ranges between $4.8 \%$ and $10.3 \%$.

\section{DISCUSSION}

$\mathrm{Cr}$ and $\mathrm{Nb}$ contents are small, as occurs in kaolin deposits of hypogene origin (Dill et al., 2000) (Fig. 7b). Kaolinites formed from hydrothermal alteration of acid-type igneous rocks show enrichment in $\mathrm{Ba}$ and $\mathrm{Sr}$, whereas $\mathrm{Cr}, \mathrm{Nb}, \mathrm{Ti}$ and the lanthanides tend to concentrate in kaolinites formed from meteoric processes (Dill et al., 1997). The large $\mathrm{Ba}+\mathrm{Sr}$ contents in the kaolinized zone in the Loma Blanca mine (well above $1000 \mathrm{ppm})$ and the small $\mathrm{Ce}+\mathrm{Y}+\mathrm{La}$ contents $(<100 \mathrm{ppm})$ (Fig. 7a) suggest a hypogene origin. $\mathrm{Zr}$ is a good indicator of the degree of meteorization of the parent rocks and $\mathrm{Ti}$ is a geochemically 
TABLE 3. Chemical analyses of trace elements in samples from the Loma Blanca mine (ppm).

\begin{tabular}{lrrrrrrrrrrrrr}
\hline Sample & $\mathrm{Sc}$ & $\mathrm{V}$ & $\mathrm{Ba}$ & $\mathrm{Sr}$ & $\mathrm{Y}$ & $\mathrm{Zr}$ & $\mathrm{Cr}$ & $\mathrm{Co}$ & $\mathrm{Ni}$ & $\mathrm{Cu}$ & $\mathrm{Zn}$ & $\mathrm{Ga}$ & $\mathrm{As}$ \\
\hline 01 & 12 & 204 & 292 & 564 & 14 & 153 & 50 & 25 & 140 & 30 & 130 & 22 & 6 \\
02 & 9 & 168 & 1106 & 503 & 14 & 178 & $<20$ & 26 & $<20$ & 10 & 130 & 22 & $<5$ \\
03 & 9 & 177 & 330 & 539 & 15 & 179 & $<20$ & 26 & $<20$ & 20 & 180 & 24 & $<5$ \\
04 & 11 & 214 & 948 & 92 & 13 & 159 & $<20$ & 34 & 50 & 30 & 350 & 19 & 15 \\
05 & 17 & 391 & 928 & 2301 & 47 & 127 & 120 & 6 & 20 & 70 & 40 & 25 & 12 \\
06 & 5 & 147 & 217 & 2525 & $<2$ & 121 & 30 & $<1$ & $<20$ & $<10$ & $<30$ & 26 & 10 \\
07 & 5 & 131 & 166 & 1902 & $<2$ & 123 & $<20$ & $<1$ & $<20$ & $<10$ & $<30$ & 22 & 8 \\
08 & 2 & 115 & 1109 & 1504 & $<2$ & 58 & 30 & $<1$ & $<20$ & $<10$ & $<30$ & 32 & 13 \\
09 & 5 & 149 & 577 & 2529 & $<2$ & 156 & 30 & $<1$ & $<20$ & 10 & $<30$ & 27 & 9 \\
10 & 7 & 132 & 2727 & 1992 & 3 & 116 & 60 & 5 & $<20$ & 20 & 40 & 23 & 5 \\
11 & 8 & 277 & 626 & 1037 & $<2$ & 180 & $<20$ & 2 & $<20$ & 10 & $<30$ & 24 & 7 \\
12 & 4 & 120 & 1743 & 2030 & $<2$ & 160 & $<20$ & $<1$ & $<20$ & $<10$ & 40 & 12 & 11 \\
13 & 5 & 129 & 864 & 1688 & 2 & 272 & $<20$ & $<1$ & $<20$ & $<10$ & $<30$ & 13 & 12 \\
14 & 6 & 317 & 1093 & 1740 & 5 & 150 & 30 & $<1$ & $<20$ & $<10$ & $<30$ & 18 & 9 \\
15 & 6 & 232 & 5990 & 4765 & $<2$ & 171 & $<20$ & $<1$ & $<20$ & $<10$ & $<30$ & 22 & 13 \\
16 & 10 & 178 & 585 & 1696 & $<2$ & 244 & 40 & $<1$ & $<20$ & $<10$ & 40 & 18 & 11 \\
17 & 7 & 149 & 860 & 1766 & $<2$ & 120 & 40 & $<1$ & $<20$ & 10 & 40 & 18 & 12 \\
18 & 7 & 109 & 796 & 1918 & $<2$ & 165 & 20 & $<1$ & $<20$ & $<10$ & $<30$ & 17 & 8 \\
19 & 4 & 117 & 533 & 1756 & $<2$ & 144 & 30 & $<1$ & $<20$ & $<10$ & $<30$ & 14 & 10 \\
20 & 9 & 146 & 955 & 4499 & 2 & 192 & 50 & $<1$ & $<20$ & 60 & $<30$ & 27 & 45 \\
& & & & & & & & & & & & & \\
\hline
\end{tabular}

Table 3 (cont).

\begin{tabular}{|c|c|c|c|c|c|c|c|c|c|c|c|c|c|}
\hline Sample & $\mathrm{Rb}$ & $\mathrm{Nb}$ & Mo & $\mathrm{Ag}$ & $\mathrm{Sb}$ & $\mathrm{Hf}$ & $\mathrm{Ta}$ & W & $\mathrm{Tl}$ & $\mathrm{Pb}$ & $\mathrm{Bi}$ & $\mathrm{Th}$ & U \\
\hline 01 & 26 & 6 & 7 & 5.1 & 5.5 & 4.0 & 0.4 & $<1$ & 0.4 & 46 & $<0.4$ & 4.2 & 1.1 \\
\hline 02 & 24 & 6 & 2 & 2.7 & 6.6 & 4.6 & 0.4 & $<1$ & 0.4 & 8 & $<0.4$ & 5.0 & 1.2 \\
\hline 03 & 25 & 7 & 3 & 1.7 & 6.3 & 5.4 & 0.4 & $<1$ & 0.4 & 7 & $<0.4$ & 5.4 & 1.3 \\
\hline 04 & 73 & 6 & 7 & 1.7 & 5.2 & 4.6 & 0.4 & $<1$ & 1.3 & 15 & $<0.4$ & 5.4 & 2.3 \\
\hline 05 & 95 & 5 & 3 & $<0.5$ & $<0.5$ & 3.5 & 0.3 & 2 & 0.6 & 14 & $<0.4$ & 4.4 & 4.5 \\
\hline 06 & $<2$ & 4 & $<2$ & $<0.5$ & 6.4 & 3.1 & 0.2 & $<1$ & 0.2 & 19 & $<0.4$ & 3.1 & 1.2 \\
\hline 07 & $<2$ & 5 & $<2$ & $<0.5$ & 5.3 & 3.4 & 0.3 & $<1$ & $<0.1$ & 26 & $<0.4$ & 3.6 & 0.6 \\
\hline 08 & $<2$ & $<1$ & $<2$ & $<0.5$ & 6.7 & 1.4 & $<0.1$ & $<1$ & $<0.1$ & 37 & $<0.4$ & 2.3 & 0.3 \\
\hline 09 & $<2$ & 7 & $<2$ & $<0.5$ & 6.8 & 4.3 & 0.3 & $<1$ & $<0.1$ & 37 & $<0.4$ & 4.0 & 0.7 \\
\hline 10 & 6 & 6 & $<2$ & 0.6 & 1.9 & 2.9 & 0.4 & $<1$ & 0.1 & 36 & $<0.4$ & 3.8 & 1.0 \\
\hline 11 & 30 & 7 & 2 & 2.7 & 0.9 & 4.5 & 0.4 & 1 & 0.6 & 41 & 0.7 & 7.1 & 3.6 \\
\hline 12 & $<2$ & 5 & $<2$ & 4.3 & 11.6 & 4.5 & 0.3 & $<1$ & $<0.1$ & 19 & $<0.4$ & 4.0 & 1.0 \\
\hline 13 & $<2$ & 4 & $<2$ & 0.7 & 6.7 & 7.1 & 0.2 & $<1$ & $<0.1$ & 16 & $<0.4$ & 4.1 & 1.5 \\
\hline 14 & $<2$ & 4 & 4 & 1.7 & 15.2 & 4.0 & 0.2 & 2 & $<0.1$ & 52 & $<0.4$ & 5.9 & 2.2 \\
\hline 15 & 6 & 5 & 6 & 6.9 & 11.0 & 4.9 & 0.2 & 2 & 0.2 & 191 & 0.6 & 24.6 & 5.8 \\
\hline 16 & $<2$ & 5 & $<2$ & 1.8 & 7.0 & 6.3 & 0.3 & 1 & $<0.1$ & 110 & $<0.4$ & 4.7 & 1.6 \\
\hline 17 & $<2$ & 5 & 6 & 1.4 & 8.3 & 3.6 & 0.4 & 1 & 0.2 & 211 & $<0.4$ & 5.5 & 1.4 \\
\hline 18 & $<2$ & 5 & $<2$ & 1.3 & 1.8 & 3.9 & 0.4 & 1 & $<0.1$ & 68 & $<0.4$ & 6.3 & 1.3 \\
\hline 19 & $<2$ & 4 & $<2$ & 4.0 & 10.3 & 4.0 & 0.2 & $<1$ & $<0.1$ & 158 & $<0.4$ & 5.9 & 1.1 \\
\hline 20 & $<2$ & 7 & 4 & 5.2 & 5.1 & 4.5 & 0.4 & 2 & $<0.1$ & 143 & $<0.4$ & 11.1 & 1.7 \\
\hline
\end{tabular}

immobile element under surface conditions. Therefore kaolins with large $\mathrm{Zr}$ and $\mathrm{Ti}$ contents indicate a near-surface formation environment. In Fig. $7 \mathrm{c}$ it can be seen that the contents of these elements in the Loma Blanca mine allow classification of these rocks as kaolins of hypogene origin. Likewise, $\mathrm{Fe}$ tends to be concentrated mainly during supergene processes. The $\mathrm{Fe}_{2} \mathrm{O}_{3}+$ $\mathrm{TiO}_{2}$ content in this kind of deposit is above $1 \%$. In Fig. $7 b$ it can be seen that the content of these 

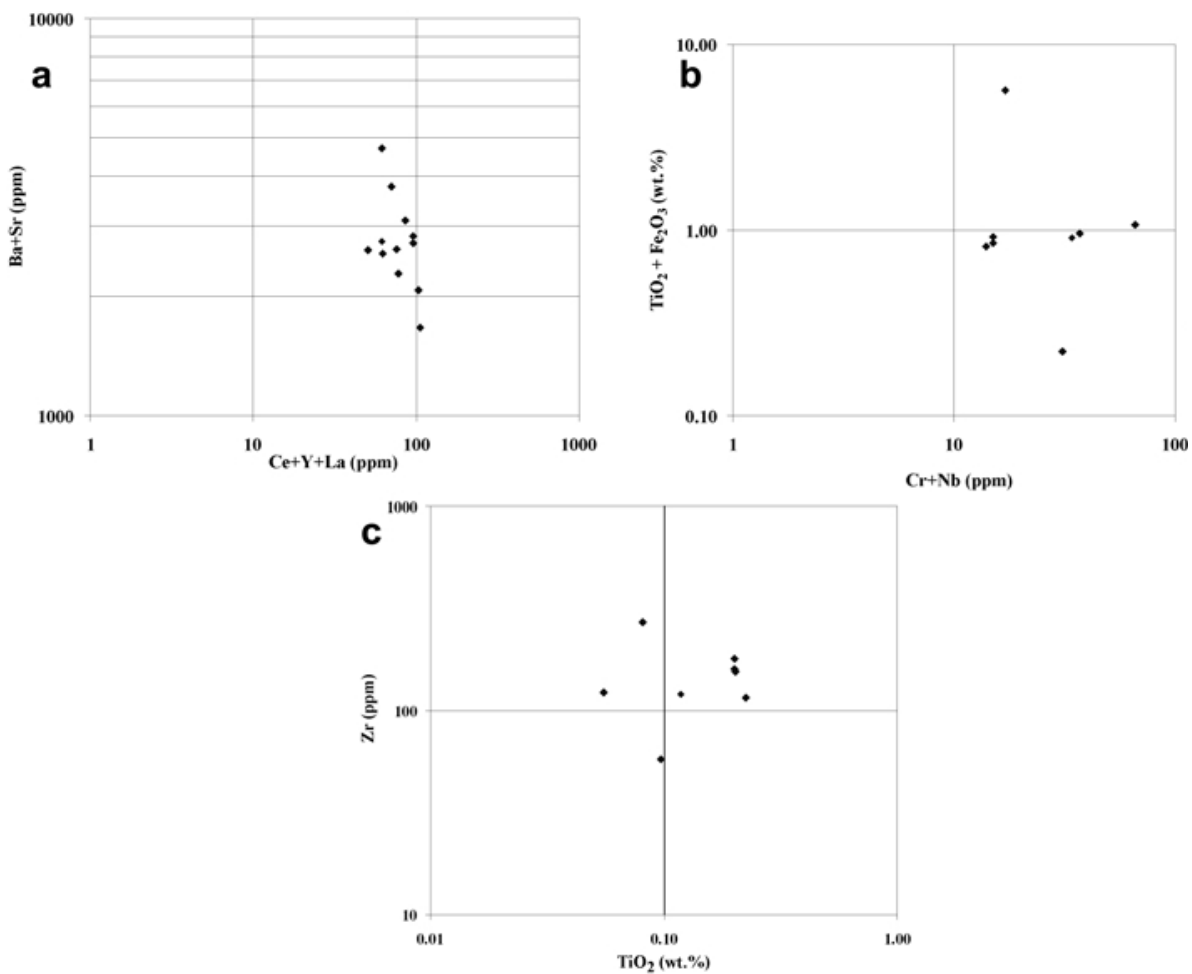

Fig. 7. Data plot of samples from argillic zone. (a) $\mathrm{Ba}+\mathrm{Sr} v s$. $\mathrm{Ce}+\mathrm{Y}+\mathrm{La}$. (b) $\mathrm{Fe}_{2} \mathrm{O}_{3}+\mathrm{TiO}_{2} v s$. $\mathrm{Cr}+\mathrm{Nb}$. (c) $\mathrm{Zr}$ vs. $\mathrm{TiO}_{2}$.

elements provides evidence for a hypogene origin. The large $\mathrm{Fe}_{2} \mathrm{O}_{3}$ content in sample 11 is attributed to the presence of pyrite, which was identified in polished sections.

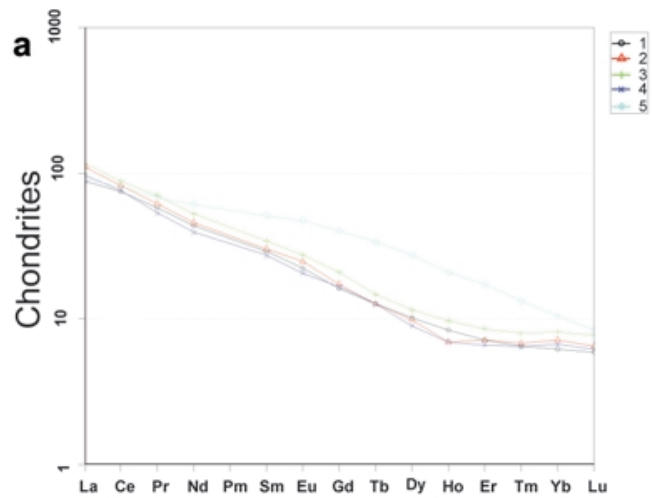

Although the $\delta^{18} \mathrm{O}$ values in kaolinites are large, they are within the ranges corresponding to hydrothermal kaolins. It is assumed that mixing with meteoric waters has occurred, which changed



FIG. 8. (a) REE in the intermediate propylitic and sericitic alteration zones. (b) REE in the intermediate argillic alteration and advanced argillic alteration zones. 
TABLE 4. $\delta^{18} \mathrm{O}$ and $\delta \mathrm{D} \%$ values of kaolin samples from the Loma Blanca mine.

\begin{tabular}{lcc}
\hline Sample & $\delta^{18} \mathrm{O}_{\text {SMOW }} \%$ & $\delta \mathrm{D}_{\text {SMOw }} \%$ \\
\hline 6 & 10.8 & -83 \\
08 & 13.2 & -84 \\
09 & 12.1 & -85 \\
20 & 10.4 & -843 \\
\hline
\end{tabular}

the physicochemical conditions of the solutions. Evidence is provided by the relict morphology of diaspore and its hydration, which led to the formation of boehmite and to the residual form of pyrophyllite areas. The results of $\delta^{18} \mathrm{O}$ and $\delta \mathrm{D}$ obtained for other deposits in the area (Blanquita and Equivocada mines) are compared with those of the Loma Blanca mine in Fig. 9.

A schematic summary of the paragenetic sequence is given in Table 5. The main Al minerals of higher temperature occur predominantly in the central area below the silicified zone, which is responsible for protecting the deposit from subsequent erosion processes. Dickite and nacrite frequently occur in deposits of hydrothermal

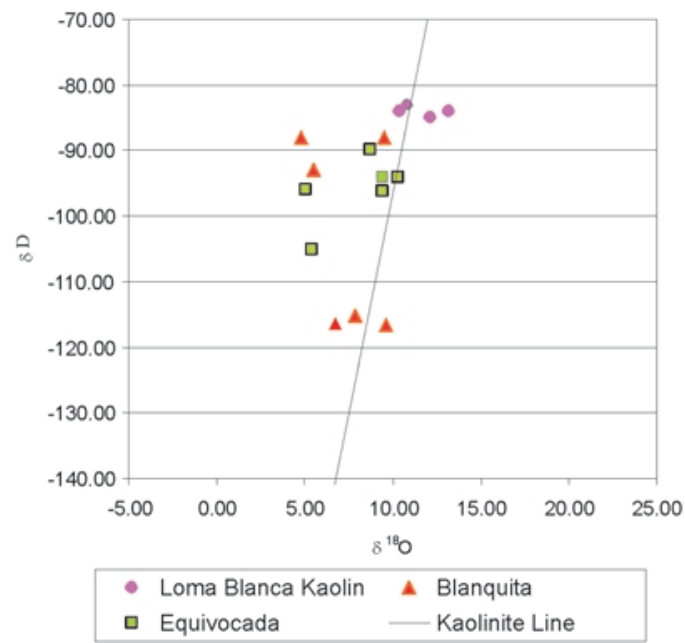

FIG. 9. $\delta^{18} \mathrm{O}$ and $\delta \mathrm{D}$ values in Loma Blanca kaolins are compared with those from the Blanquita and Equivocada mines.

origin (Murray, 1988). Numerous authors have synthesized pyrophyllite at temperatures above $260^{\circ} \mathrm{C}$ (Grim, 1969; Roy \& Osborn, 1954; Hemley, 1959; Reed \& Hemley, 1967; and Tzuzuki \& Mizutani, 1971). The coexistence of

TABLE 5. Summary of the paragenetic sequence.

\begin{tabular}{|c|c|c|c|c|c|}
\hline Mineral & $\begin{array}{l}\text { Silicified } \\
\text { zone }\end{array}$ & $\begin{array}{l}\text { Advanced } \\
\text { argillic zone }\end{array}$ & $\begin{array}{l}\text { Intermediate } \\
\text { argillic zone }\end{array}$ & $\begin{array}{l}\text { Sericitic } \\
\text { zone }\end{array}$ & $\begin{array}{c}\text { Propylitic } \\
\text { zone }\end{array}$ \\
\hline \multicolumn{6}{|l|}{ Quartz } \\
\hline \multicolumn{6}{|l|}{ Diaspore } \\
\hline \multicolumn{6}{|l|}{ Natroalunite } \\
\hline \multicolumn{6}{|l|}{ Pyrophillite } \\
\hline \multicolumn{6}{|l|}{ Dickite } \\
\hline \multicolumn{6}{|l|}{ Kaolinite } \\
\hline \multirow{2}{*}{\multicolumn{6}{|c|}{ Illite }} \\
\hline & & & & & \\
\hline Chlorite & & & & & \\
\hline
\end{tabular}


pyrophyllite and kaolinite allows estimating a maximum temperature of $350^{\circ} \mathrm{C}$.

Diaspore can be recognized frequently in kaolin deposits of hydrothermal origin. According to Roy \& Osborn (1954), the boehmite-diaspore transformation temperature is between 270 and $300^{\circ} \mathrm{C}$ at 175-1500 atm. water pressure.

\section{CONCLUSIONS}

(1) The mineral assemblage (dickite-natroalunitepyrophyllite-diaspore), the alteration zonation pattern (laterally concentric), the geochemistry of trace elements, the relation between LREE and HREE and the small $\delta^{18} \mathrm{O}$ values suggest that the Loma Blanca deposit was formed by hydrothermal processes.

(2) Mineralization developed in two stages: the first stage, of higher temperature, led to the formation of dickite, pyrophyllite and diaspore. Then the temperature decreased due to contamination with meteoric water, and alunite and kaolinite developed.

(3) The mineral assemblage allows estimating a formation temperature between 270 and $350^{\circ} \mathrm{C}$.

\section{ACKNOWLEDGMENTS}

The authors wish to thank the Comisión de Investigaciones Científicas, the Departamento de Geología de la UNS; the CONICET and Mr Rodoflo Salomón for their helpful support during the research.

\section{REFERENCES}

Cravero F., Domínguez E. \& Iglesias C. (2001) Genesis and applications of the Cerro Rubio kaolin deposit, Patagonia (Argentina). Applied Clay Science, 18, $157-172$.

Dill H (2001) The geology of aluminium phosphates and sulphates of the alunite group minerals: a review. Earth Science Reviews, 53, 35-93.

Dill H.G., Bosse H.-R., Henning K.-H. \& Fricke A. (1997) Mineralogical and chemical variations in hypogene and supergene kaolin deposits in a mobile fold belt-The Central Andes of northwestern Peru. Mineralium Deposita, 32, 149-163.

Dill H., Bosse H.-R. \& Kassbohm J. (2000) Mineralogical and chemical studies of volcanicrelated argillaceous industrial minerals of the Central American Cordillera (Western El Salvador). Economic Geology, 95, 517-538.

Ece Ö, Schroeder A.P., Smilley M.J. \& Wampler J.M.
(2008) Acid-sulphate hydrothermal alteration of andesitic tuffs and genesis of halloysite and alunite deposits in the Biga Peninsula, Turkey. Clay Minerals, 43, 281-315.

Grim H. (1969) Clay Mineralogy. $2^{\text {nd }}$ Edition. Pp. 131-137. McGraw Hill Book Co, New York, USA.

Hayase K. \& Maiza P. (1974) Génesis del yacimiento de caolín de mina Loma Blanca, Los Menucos, Provincia de Río Negro, Argentina. V Congreso Geológico Argentino. Buenos Aires, Argentina, 139-151.

Hemley J.J. (1959) Some mineralogical equilibria in the system $\mathrm{K}_{2} \mathrm{O}-\mathrm{Al}_{2} \mathrm{O}_{3}-\mathrm{SiO}_{2}-\mathrm{H}_{2} \mathrm{O}$. American Journal of Science, 257, 241-270.

Labudia C. \& Bjerg E. (1994) Geología del sector oriental de la hoja Bajo Hondo (39e), Provincia de Río Negro. Revista de la Asociación Geológica Argentina, 49, 284-296.

Maiza P. (1972) Los yacimientos de caolín originados por la actividad hidrotermal en lo principales distritos caoliníferos de la Patagonia, República Argentina. PhD thesis, Universidad Nacional del Sur. Argentina.

Maiza P. \& Mas G. (1980) Estudio de los sulfatos alunita-natroalunita. Síntesis de la serie. Revista de la Asociación Argentina de Mineralogía, Sedimentología y Petrología, 11, 32-41.

Maiza P. \& Mas G. (1981) Presencia de natroalunita en Mina Equivocada, Río Negro. Su significado. 8th Congreso Geologico Argentino, San Luis, Actas IV, 285-292.

Maiza P.J., Pieroni D. \& Marfil S.A. (2003) Geochemistry of the hydrothermal kaolins in the SE area of Los Menucos. Prov. de Río Negro. A clay odyssey. Proceedings of the 12th International Clay Conference. Argentina, 2001, Elsevier, 123-130.

Maiza P.J., Marfil S.A. \& Montecchiari N. (2009) Alteration zonation 'Loma Blanca' kaolin deposit, Los Menucos, Rio Negro Province, Argentina. XIV Internacional Clay Conference, Abstracts Vol. 1, p. 188.

Marfil S.A., Pieroni D. \& Maiza P.J. (2000) Dickita y alunita en mina Blanquita. Los Menucos. (Province de Río Negro). $V$ Congreso de Mineralogía y Metalogenia. MINMET 2000, La Plata. Argentina, 281-286.

Marfil S.A., Maiza P.J., Cardellach E.. \& Corbella M. (2005) Origin of kaolin deposits in the 'Los Menucos', Río Negro Province, Argentina. Clay Minerals, 40, 283-293.

Murray H. \& Janssen J. (1984) Oxygen isotopes-indicators of kaolin genesis? Proceedings of the $27^{\text {th }}$ International Geological Congress, 15, 287-303.

Pandarinath K., Dulski P. Torres Alvarado I.S. \& Verma S.P. (2008) Element mobility during the hydrothermal alteration of rhyolitic rocks of the Los Azufres geothermal field, Mexico. Geothermics, 37, 53-72. 
Pankurst R.J.C., Rapela W., Caminos R., Llambías E. \& Parica C. (1992) A revised age for the granites of the central Somoncura Batholith, North Patagonian Massif. Journal of South American Earth Sciences, 5, 321-325.

Papoulis D. \& Tsolis-Katagas P. (2008) Formation of alteration zones and kaolin genesis, Limnos Island, northeast Aegean Sea, Greece. Clay Minerals, 43, 631-646.

Papoulis D., Tsolis-Katagas P. \& Katagas C. (2004). Monazite alteration mechanisms and depletion measurements in kaolins. Applied Clay Science, 24. $271-285$.

Reed B.L. \& Hemley J.J. (1967) Ocurrence of pyrophyllite in Kekiktuk Conglomerate. Pp. 162-166 in: Book Range, Northeastern Alaska.
U.S. Geological Survey.

Rollinson H. (1992) Using geochemical data: Evaluation, presentation, interpretation. University of Zimbabwe.

Roy R. \& Osborn E. (1954) The system $\mathrm{Al}_{2} \mathrm{O}_{3}-\mathrm{SiO}_{2}-$ $\mathrm{H}_{2} \mathrm{O}$. American Mineralogist, 39, 853-885.

Terakado Y. \& Fujitani T. (1998) Behavior of the rare earth elements and other trace elements during interactions between acidic hydrothermal solutions and silicic volcanic rocks, southwestern Japan. Geochimica et Cosmochimica Acta, 62, 1903-1998.

Tzuzuki Y. \& Mizutani S. (1971) A study of rock alternation process based on kinetics of hydrothermal experiment. Contributions to Mineralogy and Petrology, 30, 15-33. 
